\title{
Hydrogeochemical Assessment of Groundwater in the Precambrian Rocks, South Eastern Desert, Egypt
}

\author{
Ashraf Embaby1,2, Moumtaz Razack ${ }^{1 *}$, Mathieu Lecoz' ${ }^{1}$, Gilles Porel1 \\ ${ }^{1}$ Department of Hydrogeology, University of Poitiers, Poitiers, France \\ ${ }^{2}$ Geology Department, Faculty of Science, Sohag University, Sohag, Egypt \\ Email: *moumtaz.razack@univ-poitiers.fr
}

Received 16 September 2015; accepted 20 March 2016; published 23 March 2016

Copyright (C) 2016 by authors and Scientific Research Publishing Inc.

This work is licensed under the Creative Commons Attribution International License (CC BY). http://creativecommons.org/licenses/by/4.0/

(c) (†) Open Access

\begin{abstract}
This work refers to the characterization of the hydrochemistry of the southern part of the Eastern Desert in Egypt, on the basis of physico-chemical properties of groundwater occurring in the fractured Precambrian rocks inland and in sedimentary formations on the coastline of the Red Sea. Thirty-five groundwater samples have been collected from the study area for hydrochemical investigations to understand the sources of dissolved ions and assess the chemical quality of the groundwater. Several methods were used to interpret the hydrochemical data, i.e. graphical methods, principal components analysis, ions exchanges indices and saturation indices of various minerals. The results show that the major ionic relationships are $\mathrm{Na}^{+}>\mathrm{Ca}^{2+}>\mathrm{Mg}^{2+}$ and $\mathrm{Cl}^{-}>\mathrm{SO}_{4}^{2-}>$ $\mathrm{HCO}^{3-}$ and that groundwater chemical characteristics are controlled by natural geochemical processes but also, to a lesser extent, by anthropogenic activities. Natural minerals dissolution, ion exchanges and evaporation play a prominent role in the ion enrichment of groundwater. A comparison of groundwater quality in relation to WHO water quality standards proved that most of the water samples are not totally suitable for drinking water purpose.
\end{abstract}

\section{Keywords}

Eastern Desert, Pre-Cambrian Rocks, Groundwater, Hydrochemistry, Principal Components Analysis, Egypt

\section{Introduction}

Groundwater resource assessments and sustainability considerations are of utmost importance in the arid and

"Corresponding author.

How to cite this paper: Embaby, A., Razack, M., Lecoz, M. and Porel, G. (2016) Hydrogeochemical Assessment of Groundwater in the Precambrian Rocks, South Eastern Desert, Egypt. Journal of Water Resource and Protection, 8, $293-310$. 
semiarid regions, where water is commonly of critical economical and social significance. Egypt is facing this situation. In this country water needs are dramatically increasing, demanded by a rapidly growing population, increased urbanization, higher standards of living and agricultural policy. The World Bank describes Egypt as a country being under water stress. Limited natural fresh water resources in the Eastern Desert of Egypt call for evaluation of water resources in the area. The Eastern Desert represents $22 \%$ of the total area of the country. It houses both residential areas, commercial and industrial zones, as well as tourist villages. Groundwater is a significant and crucial resource in many areas in Egypt and it commonly plays a key role as a water supply for drinking, irrigation and industries. It represents a vital resource in the Eastern Desert due to the unavailability of other sources.

Despite importance of groundwater in the study area, little is known about the natural phenomena that govern the chemical composition of groundwater or anthropogenic factors that presently affect them. The chemical composition of groundwater is controlled by many factors that include composition of precipitation, geological structure and mineralogy of the watersheds and aquifers, and geochemical processes within the aquifer [1]. The interaction of all factors leads to various water types. Thus the purpose of the present study is to determine the current hydrochemical status of the southeastern desert groundwater and understand the mineralization processes. Major chemical ions $\left(\mathrm{Ca}^{2+}, \mathrm{Mg}^{2+}, \mathrm{Na}^{+}, \mathrm{K}^{+}, \mathrm{Cl}^{-}, \mathrm{HCO}^{3-}, \mathrm{NO}^{3-}, \mathrm{SO}_{4}^{2-}\right)$ were analyzed for this purpose. Samples were collected in 35 wells distributed all over the study area. The interpretation of hydrochemical data was made using various methods (Piper diagram, principal component analysis, base exchanges index, bi-elements scatter diagrams, saturation indices, and mapping). The objective aims at improving the knowledge of geochemical evolution of groundwater in this arid and semi-arid region, leading to sustainable development and effective management of groundwater resource.

\section{Location of the Study Area}

The Eastern Desert covers about 220,000 $\mathrm{km}^{2}$ and is located between the Red Sea and the Nile Valley. It extends from latitude $22 \mathrm{~N}$ and $29 \mathrm{~N}$ or Egypt's borders with Sudan in the South, to the Delta in the North [2]. It forms around 22\% of Egypt's surface area, and extends on average over $1100 \mathrm{~km}$ from North to South, and $225 \mathrm{~km}$ from East (Nile Valley) to West (Red Sea). But it was undeveloped due to the limited availability of water [3]. The Eastern Desert consists of high rugged mountains parallel to the coast and flanked to the north and west by dissected sedimentary plateau [4]. The study area (Figure 1) is located in the Southern part of the Eastern Desert (South Eastern Desert) and extends from El-Baramia area in Idfu-Marsa Alam road to Marsa Alam-Abu Ghuson on the Red Sea coast. The study area covers an area about $16800 \mathrm{~km}^{2}$ and is limited by longitudes $33^{\circ} 50 /$ $35^{\circ} 45 / \mathrm{E}$ and latitudes $24^{\circ} 00 /-25^{\circ} 15 / \mathrm{N}$.

The Eastern Desert is located in the extremely arid provinces in Egypt. Temperature ranges from $21^{\circ} \mathrm{C}$ to $41^{\circ} \mathrm{C}$. Rainfall is considerably variable from one season to another. The average annual rainfall ranges from 3 to $50 \mathrm{~mm} /$ year on the southern part of the desert.

\section{Geological and Hydrogeological Setting}

The Eastern Desert is geologically composed mainly of sedimentary and Pre-Cambrian crystalline rocks. The crystalline rocks of the Pre-Cambrian basement complex form massive formations extending parallel to the Red Sea graben and consist mainly of metamorphic and igneous rocks [4] [5]. The sedimentary rocks are found on the coastal plain and overlain the Pre-Cambrian basement rocks. They consist of Quaternary alluvial sediments and Tertiary formations (sandstones interbedded with clays, evaporites intercalated with clay and sand) [6] [7]. The quaternary aquifer in the Eastern Desert is represented by wadi sediments and alluvial plains [2].

The groundwater occurrence in fractured igneous and metamorphic water bearing formations in the Eastern Desert of Egypt is controlled by the presence, width and direction of the joints, fractures, faults and dykes and thickness of weathering zones [8] [9]. The hydrogeological rock units in South Eastern Desert are classified into Red Sea Coastal aquifers formed by coastal Quaternary and Miocene formations, and fractured Pre-Cambrian basement aquifer composed of meta-volcanics, basic-ultrabasic rocks, granites and metasediments (schists and gneisses) (Table 1 and Figure 1). Embaby et al. [10] using geophysical methods, concluded that the structure of the study area can be schematized with three main layers, i.e. the wadi deposits 15 - $60 \mathrm{~m}$ thick, the fractured basement rock 20 - $100 \mathrm{~m}$ thick and massive basement rocks 40 - $250 \mathrm{~m}$ thick.

At the scale of the Eastern Desert, fractured Precambrian formations can be considered as a continuous medium. 


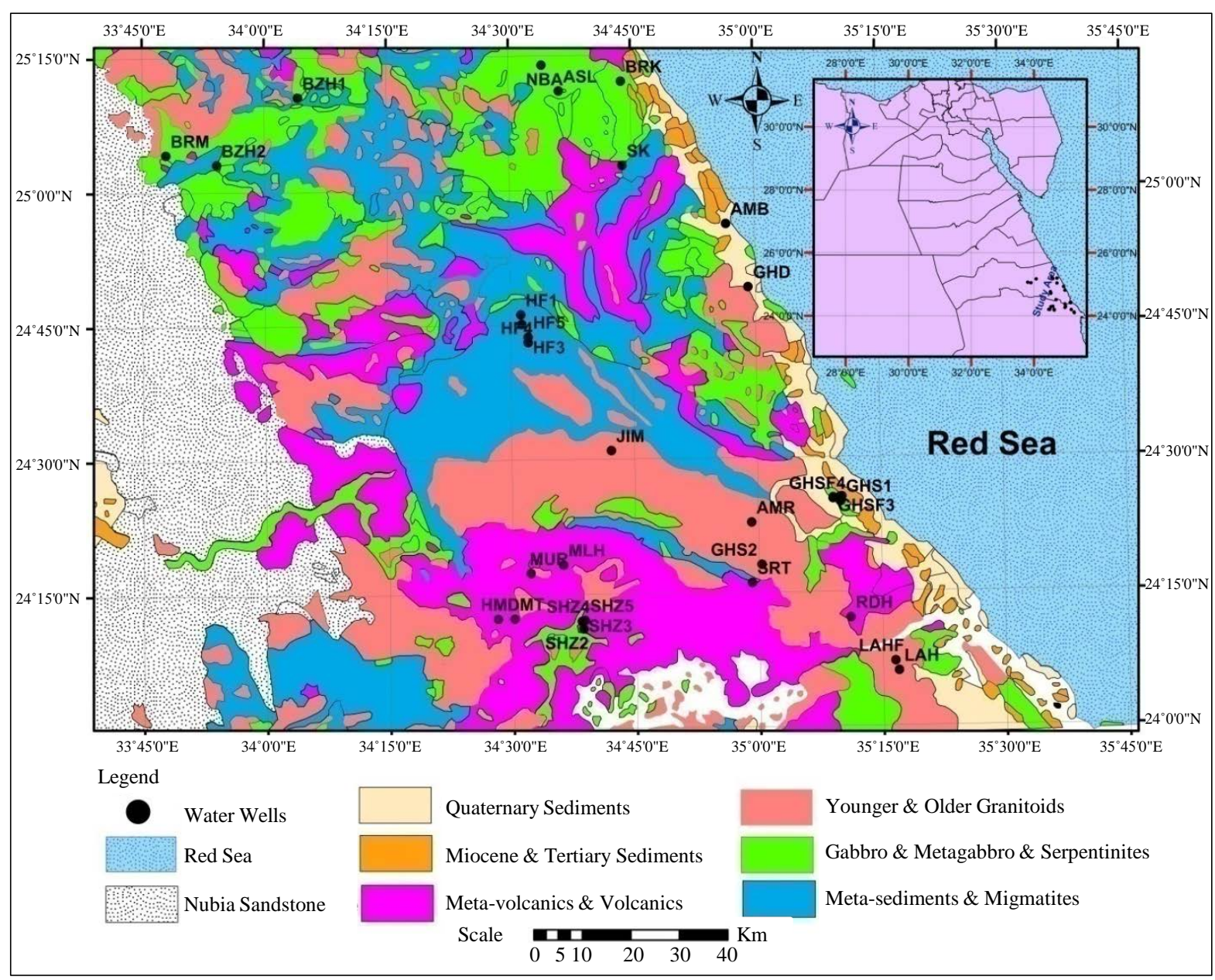

Figure 1. Simplified geological map of the study area and groundwater samples locations (modified from Aswan geological map, 1979).

A piezometric map (Figure 2) throughout the study area has thereby been established. It highlights a groundwater divide line from South to the North. To the west of this line, groundwater flows to the Nile. To the east the flow is towards the Red Sea. Recharge takes place from the occasional rainfalls. The mountainous zones probably act as preferential recharge zones.

\section{Sampling and Analytical Procedure}

A sampling network was set up to allow collection of representative data of the variability in space of the groundwater quality. This network consisted of 35 wells and covers the whole area (Figure 1). The rocks types of the aquifers where the wells were drilled are shown in Table 1.

Water samples were collected during two field campaigns, June 2013 and March 2014 in wells that form the observation network, because of great difficulties to access to the sites. Groundwater samples were filtered and collected in $0.5 \mathrm{~L}$ polyethylene bottles. All samples were stored in ice-boxes and then in a refrigerator in Egypt, before being sent to Poitiers in France. The analyses focused on the most common and most abundant ions in groundwater. The analyses were performed at the University of Poitiers for alkalinity and $\mathrm{Cl}^{-}$using titration methods, and at the University of Pau, using an ICP-MS (Inductively Coupled Plasma Mass Spectrometry) for other cations and anions $\left(\mathrm{Ca}^{2+}, \mathrm{Mg}^{2+}, \mathrm{Na}^{+}, \mathrm{K}^{+}, \mathrm{HCO}_{3}^{-}, \mathrm{NO}_{3}^{-}, \mathrm{SO}_{4}^{2-}, \mathrm{Br}^{-}\right)$. Note that for dosing $\mathrm{Cl}^{-}$by titration with $\mathrm{AgNO}_{3}$, to avoid interference with sulfates, one to two drops of hydrogen peroxide $\left(\mathrm{H}_{2} \mathrm{O}_{2}\right)$ at $30 \%$ were added while maintaining agitation. Temperature and $\mathrm{pH}$ were measured in the field. The ion-balance error computation, taking the relationship between the total cations $\left(\mathrm{Ca}^{2+}, \mathrm{Mg}^{2+}, \mathrm{Na}^{+}, \mathrm{K}^{+}\right)$and the total anions $\left(\mathrm{NO}_{3}^{-}\right.$, 


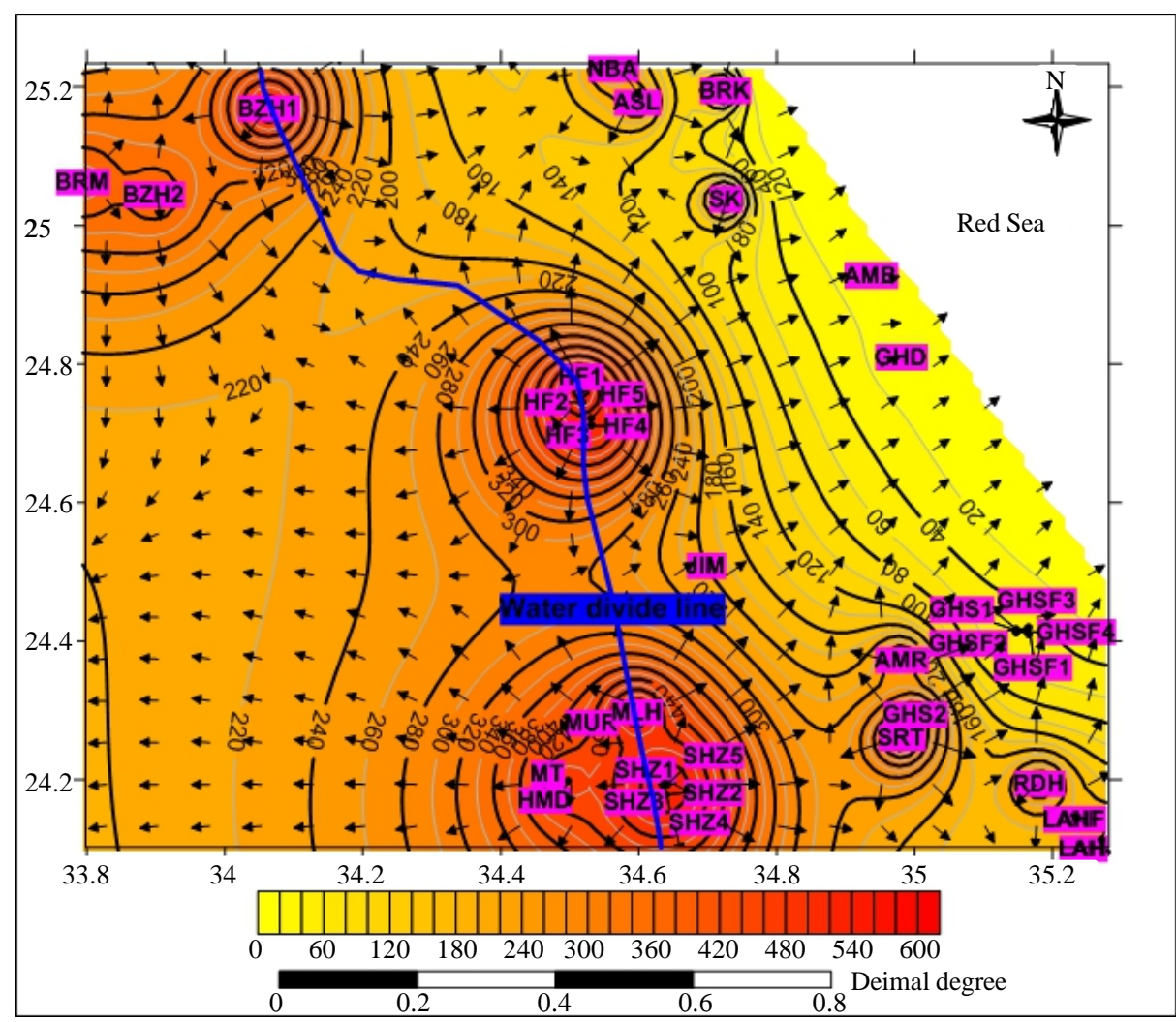

Figure 2. Piezometric map of the study area.

Table 1. Aquifer rock types and groundwater samples.

\begin{tabular}{|c|c|c|c|}
\hline No. & Aquifer rock units & Wells No. & Wells locations \\
\hline 1 & Meta-volcanic (Meta-andesite, meta-basalt) & $\begin{array}{l}1,4,5,6,7,8,9,10 \\
11,12 \text { and } 26\end{array}$ & $\begin{array}{l}\text { Sukkari, El-Shazly }{ }_{1-5} \text {, Abu Himimid, Miteiwit, } \\
\text { Murirah, Malahaia and El-Barramia }\end{array}$ \\
\hline 2 & $\begin{array}{l}\text { Basic-ultrabasic (Gabbro, serpentinites, } \\
\text { Meta-gabbro-diorite complex) }\end{array}$ & 25, 26x and 30 & Abu Ghuson-2, Sartut and El-Nabaa \\
\hline 3 & Granitoids (Younger and older granite rocks) & $\begin{array}{l}13,14,15,24,27,28, \\
29,31,32,33,34 \text { and } \\
35\end{array}$ & $\begin{array}{l}\text { El-Jimal, Beizah }{ }_{1-2} \text {, El-Sheikha Amira, } \\
\text { Hafafit } 3 \text { 3-5, El-Asly, Lahmi, Lahmi-FAO, } \\
\text { El-Reidah and Barikah }\end{array}$ \\
\hline 4 & Meta-sediment (Schists, gneisses) & 2 and 3 & Hafaifit $_{1-2}$ \\
\hline 5 & Quaternary (Alluvium, recent sediments) & $\begin{array}{l}16,17,19,20,21 \text { and } \\
22\end{array}$ & Ambaout, Ghadir, Abu Ghuson $\mathrm{FAO}_{1-4}$ \\
\hline 6 & $\begin{array}{l}\text { Miocene (Coral reefs, sandstones, carbonate, } \\
\text { evaporites) }\end{array}$ & 18 & Abu Ghuson-1 \\
\hline
\end{tabular}

$\mathrm{SO}_{4}^{2-}, \mathrm{HCO}_{3}^{-}$and $\mathrm{Cl}^{-}$) for each water sample, is observed to be within the range of acceptability ( $\left.\pm 5 \%\right)$ used in most laboratories [11], for all water samples. The hydrochemical data are given in Table 2.

\section{Major Ions Chemistry}

Table 3 shows the summary statistics for each water quality parameter. The $\mathrm{pH}$ ranges between 7.2 and 8.3 . The average $\mathrm{pH}$ is 7.7 , which indicates that the eastern desert groundwater is slightly alkaline. The lower $\mathrm{pH}$ values are located at the eastern part of the study area and reflect the connection between marine water and the sampled wells. The higher $\mathrm{pH}$ values of the western part of the study area may indicate preferential recharge areas. The groundwater temperature does not vary much and is included between $28^{\circ} \mathrm{C}$ and $29^{\circ} \mathrm{C}$. The TDS (Total Dissolved Solids) ranges from $947 \mathrm{mg} / \mathrm{l}$ to $13,504 \mathrm{mg} / \mathrm{l}$ with a mean of $5974 \mathrm{mg} / \mathrm{l}$. These figures show that the groundwater mineralization varies greatly on the study site. 
Table 2. Hydrochemical data of the South Eastern Desert groundwater samples. TDS and ions concentrations are in mg/l. Hardness is in French degree $\left({ }^{\circ} \mathrm{F}\right)$.

\begin{tabular}{|c|c|c|c|c|c|c|c|c|c|c|c|}
\hline Sample & TDS & $\mathrm{Ca}^{2+}$ & $\mathrm{Mg}^{2+}$ & $\mathrm{Na}^{+}$ & $\mathrm{K}^{+}$ & $\mathrm{HCO}_{3}^{-}$ & $\mathrm{Cl}^{-}$ & $\mathrm{SO}_{4}^{2-}$ & $\mathrm{Br}^{-}$ & $\mathrm{pH}$ & Hardness \\
\hline SK & 2656.0 & 188.1 & 94.0 & 613.0 & 7.0 & 414.8 & 812.4 & 763.4 & 0.8 & 7.7 & 86 \\
\hline HF1 & 2880.0 & 27.3 & 56.0 & 872.0 & 29.0 & 503.3 & 627.7 & 949.1 & 1.0 & 7.9 & 30 \\
\hline HF2 & 3104.0 & 73.5 & 80.0 & 977.0 & 24.0 & 553.9 & 664.7 & 1149.7 & 1.1 & 7.5 & 51 \\
\hline SHZ1 & 5017.6 & 547.7 & 104.0 & 1248.0 & 8.0 & 244.0 & 1415.5 & 2122.7 & 3.7 & 7.8 & 179 \\
\hline SHZ2 & 10304.0 & 699.3 & 115.0 & 2977.0 & 47.0 & 230.0 & 3631.1 & 3374.1 & 10.6 & 7.7 & 222 \\
\hline SHZ3 & 6848.0 & 657.6 & 135.0 & 1800.0 & 13.0 & 161.7 & 1883.2 & 3122.7 & 4.9 & 7.5 & 220 \\
\hline SHZ4 & 4115.2 & 511.2 & 91.0 & 996.0 & 3.0 & 137.3 & 1132.4 & 1922.1 & 3.4 & 7.6 & 165 \\
\hline SHZ5 & 12864.0 & 1009.3 & 77.0 & 3582.0 & 36.0 & 101.9 & 5194.3 & 3248.4 & 14.7 & 7.7 & 284 \\
\hline HMD & 2592.0 & 194.9 & 38.0 & 727.0 & 5.0 & 274.5 & 555.8 & 1122.7 & 2.5 & 7.9 & 64 \\
\hline MT & 3532.8 & 261.9 & 74.0 & 982.0 & 5.0 & 291.6 & 997.0 & 1257.4 & 3.1 & 7.6 & 96 \\
\hline MUR & 3328.0 & 252.3 & 78.0 & 880.0 & 6.0 & 268.4 & 726.2 & 1556.8 & 1.7 & 7.6 & 95 \\
\hline MLH & 3648.0 & 541.8 & 131.0 & 653.0 & 6.0 & 259.3 & 1083.2 & 1491.0 & 1.2 & 7.3 & 189 \\
\hline JIM & 947.2 & 96.7 & 31.5 & 171.9 & 4.5 & 158.6 & 270.8 & 197.6 & 0.4 & 7.8 & 37 \\
\hline BZH1 & 13504.0 & 825.6 & 1062.0 & 2879.0 & 76.0 & 109.8 & 5378.9 & 4676.5 & 5.6 & 7.8 & 643 \\
\hline BZH2 & 9408.0 & 859.4 & 402.0 & 2314.0 & 34.0 & 536.8 & 2954.1 & 4089.7 & 12.5 & 7.2 & 380 \\
\hline AMB & 7872.0 & 1014.9 & 426.0 & 1252.0 & 57.0 & 96.4 & 3200.3 & 2248.4 & 8.3 & 7.8 & 428 \\
\hline GHD & 7616.0 & 906.4 & 336.0 & 1044.0 & 39.0 & 78.1 & 3483.4 & 754.5 & 22.3 & 7.5 & 364 \\
\hline GHS1 & 10944.0 & 1550.3 & 343.0 & 1834.0 & 27.0 & 123.2 & 5366.6 & 1284.4 & 30.9 & 7.5 & 528 \\
\hline GHSF1 & 5331.2 & 609.2 & 180.0 & 1106.0 & 12.0 & 103.7 & 2412.5 & 838.3 & 7.9 & 7.7 & 226 \\
\hline GHSF2 & 9216.0 & 920.6 & 304.0 & 1814.0 & 32.0 & 125.1 & 4480.4 & 805.4 & 7.4 & 7.5 & 355 \\
\hline GHSF3 & 5504.0 & 615.5 & 181.0 & 1112.0 & 14.0 & 311.1 & 2486.4 & 772.4 & 8.4 & 7.9 & 228 \\
\hline GHSF4 & 10368.0 & 1136.0 & 344.0 & 2071.0 & 13.0 & 97.6 & 4665.0 & 1769.4 & 13.0 & 7.4 & 425 \\
\hline AMR & 1881.6 & 130.2 & 30.2 & 427.9 & 7.7 & 225.7 & 637.5 & 296.4 & 0.6 & 8.0 & 45 \\
\hline GHS2 & 3788.8 & 461.6 & 177.0 & 689.0 & 13.0 & 413.6 & 1329.3 & 1065.8 & 1.2 & 7.6 & 188 \\
\hline SRT & 5171.2 & 1014.3 & 28.0 & 967.0 & 41.0 & 62.8 & 1944.8 & 1829.3 & 3.9 & 8.1 & 265 \\
\hline BRM & 3219.2 & 186.7 & 107.0 & 927.0 & 24.0 & 707.6 & 366.0 & 1892.2 & 0.8 & 8.3 & 91 \\
\hline HF3 & 2540.8 & 121.7 & 81.0 & 706.0 & 16.0 & 329.4 & 430.8 & 1248.5 & 0.7 & 7.8 & 64 \\
\hline HF4 & 3180.8 & 74.9 & 101.0 & 1012.0 & 39.0 & 359.9 & 787.8 & 991.0 & 1.0 & 8.1 & 60 \\
\hline HF5 & 8448.0 & 235.9 & 221.0 & 2778.0 & 102.0 & 1345.4 & 2117.1 & 3517.9 & 3.4 & 8.3 & 150 \\
\hline NBA & 5056.0 & 909.1 & 102.0 & 702.0 & 28.0 & 128.0 & 2075.9 & 1173.6 & 9.8 & 8.1 & 269 \\
\hline ASL & 6240.0 & 903.0 & 88.0 & 1172.0 & 35.0 & 45.8 & 2999.5 & 637.7 & 20.1 & 7.7 & 262 \\
\hline LAH & 2969.6 & 242.8 & 75.0 & 691.0 & 7.0 & 155.6 & 1193.9 & 476.0 & 2.8 & 7.6 & 91 \\
\hline LAHF & 10880.0 & 926.9 & 407.0 & 2000.0 & 53.0 & 768.6 & 5120.4 & 724.5 & 17.1 & 7.4 & 399 \\
\hline $\mathrm{RDH}$ & 4672.0 & 907.0 & 127.0 & 740.0 & 7.0 & 125.1 & 1749.0 & 1502.9 & 4.2 & 7.3 & 279 \\
\hline BRK & 9472.0 & 1354.5 & 392.0 & 1312.0 & 34.0 & 79.3 & 4887.5 & 670.6 & 21.3 & 7.2 & 499 \\
\hline
\end{tabular}

Table 3. Summary statistics of groundwater physical and chemical parameters. Ion concentrations and TDS are in mg/l. SD: Standard Deviation; CV: Coefficient of Variation.

\begin{tabular}{|c|c|c|c|c|c|c|c|c|c|c|c|}
\hline & $\mathrm{Ca}^{2+}$ & $\mathrm{Mg}^{2+}$ & $\mathrm{Na}^{+}$ & $\mathrm{K}^{+}$ & $\mathrm{HCO}_{3}^{-}$ & $\mathrm{Cl}^{-}$ & $\mathrm{SO}_{4}^{2-}$ & $\mathrm{Br}^{-}$ & TDS & $\mathrm{T}^{\circ} \mathrm{C}$ & $\mathrm{pH}$ \\
\hline Max & 1550.3 & 1062.0 & 3582.0 & 102.0 & 1345.4 & 5378.9 & 4676.5 & 30.85 & 13504.0 & 29.0 & 8.3 \\
\hline Min & 27.3 & 28.0 & 171.9 & 3.0 & 45.7 & 270.7 & 197.6 & 0.38 & 947.2 & 28.0 & 7.2 \\
\hline Average & 599.1 & 189.1 & 1315.1 & 25.8 & 283.6 & 2258.9 & 1586.9 & 7.21 & 5974.8 & 28.4 & 7.7 \\
\hline SD & 400.1 & 192.8 & 788.7 & 21.8 & 256.4 & 1646.8 & 1086.7 & 7.46 & 3332.1 & 0.49 & 0.2 \\
\hline CV (\%) & 66.8 & 101.9 & 59.9 & 84.5 & 90.4 & 72.91 & 68.48 & 103.4 & 55.7 & 1.7 & 3.6 \\
\hline
\end{tabular}

The spatial variability of the ions contents, expressed using the coefficient of variation (CV), is significantly high $(60 \%<\mathrm{CV}<103 \%)$. Chloride concentrations range from $270 \mathrm{mg} / \mathrm{l}$ to $5378 \mathrm{mg} / \mathrm{l}$, bromide from 0 to 30 mg/l, sulfate from 197 to $4676 \mathrm{mg} / \mathrm{l}$, bicarbonate from 45 to $1345 \mathrm{mg} / \mathrm{l}$, calcium from 27 to $1550 \mathrm{mg} / \mathrm{l}$, magnesium from 28 to $1062 \mathrm{mg} / \mathrm{l}$, potassium from 3 to $102 \mathrm{mg} / \mathrm{l}$ and sodium from 171 to $3582 \mathrm{mg} / \mathrm{l}$. The relative concentrations of the cations occur in the order of $\mathrm{Na}^{+}, \mathrm{Ca}^{2+}, \mathrm{Mg}^{2+}, \mathrm{K}^{+}$and of the anions in the order of $\mathrm{Cl}^{-}, \mathrm{SO}_{4}^{2-}$, 
$\mathrm{HCO}_{3}^{-}$. No nitrate was found in the groundwater samples.

Pearson's correlation matrix [12] was used to find relationships between the elements pairwise. The correlation matrix is shown in Table 4. TDS is strongly correlated with calcium $(\mathrm{R}=0.77)$, magnesium $(\mathrm{R}=0.71)$, sodium $(\mathrm{R}=0.89)$, chloride $(\mathrm{R}=0.95)$, sulfate $(\mathrm{R}=0.58)$ and bromide $(\mathrm{R}=0.69)$. These relationships clearly identify the main elements contributing to the groundwater salinity and their tendency to follow a similar trend (e.g. due to concentration by evaporation). These elements concentration tend to increase as the salinity of the groundwater increases. The salinization of the groundwater would be expected to result from the ionic concentrations increasing due as well to evaporation of recharge water, to seawater intrusion as to the effects of interactions between the groundwater and the geological formations. The strongest correlations between elements of opposite sign combine $\mathrm{Cl}^{-}$and $\mathrm{Na}^{+}(\mathrm{R}=0.73), \mathrm{Cl}^{-}$and $\mathrm{Mg}^{2+}(\mathrm{R}=0.69)$, and $\mathrm{Cl}^{-}$and $\mathrm{Ca}^{2+}(\mathrm{R}=0.85)$. The $\mathrm{Na}^{+}$ vs. $\mathrm{Cl}^{-}$relationship suggests dissolution of halite or seawater intrusion. The dissolution of halite in water releases equal concentrations of sodium and chloride into the solution:

$$
\mathrm{NaCl} \rightarrow \mathrm{Na}^{+}+\mathrm{Cl}^{-}
$$

The strong relationships $\mathrm{Cl}^{-}-\mathrm{Mg}^{2+}$ and $\mathrm{Cl}^{-}-\mathrm{Ca}^{2+}$ suggest that cation exchange can also significantly affect groundwater composition. The positive and significant correlations between sulfate and sodium $(\mathrm{R}=0.76)$ may indicate the contributions of evaporitic salts. Agricultural activity may also contribute to these elements. Fertilizers based on potassium sulfate, ammonium sulfate and the sulfo-phosphate ammonium [13] may contribute to these elements. Other associations between ions are further interpreted in terms of processes and origin of the mineralization of the groundwater and its evolution.

\section{Principal Components Analysis}

Multivariate methods have been widely used to study the sources of variation of groundwater chemistry. Principal Components Analysis (PCA) is a multivariate statistical method, which helps to reduce a large data set with underlying linear structures into a set of variables, called Principal Components, without sacrificing much of the original information. PCA proved useful for discovering previously unsuspected relationships in the original data.

In this study a Principal Components Analysis (PCA) was performed on the chemical data for better understanding the groundwater hydrochemistry. Multivariate techniques have been applied to groundwater hydrochemistry by several authors and proved quite efficient to understand a number of geochemical processes [14]-[22].

The extraction method, i.e. "Principal Component method" looks for a solution that maximizes the explained variance with orthogonal components, which are independent of each other. The methods to help to choose the number of components are based on relations between the eigenvalues. According to the Kaiser criteria, eigenvalues larger than one [23], explaining more variance than the average component, should be kept. An additional graphical method can also be used, the Scree diagram (or the elbow criterion). In this diagram, the eigenvalues are plotted vs. the number of the components. If the points on the graph tend to level out (show an "elbow"), these eigenvalues are usually close enough to zero that they can be ignored. The data consist of 9 variables

Table 4. Correlation matrix between chemical variables. Significant correlation coefficients are in bold.

\begin{tabular}{|c|c|c|c|c|c|c|c|c|c|}
\hline & TDS & $\mathrm{Ca}^{2+}$ & $\mathrm{Mg}^{2+}$ & $\mathrm{Na}^{+}$ & $\mathrm{K}^{+}$ & $\mathrm{Cl}^{-}$ & $\mathrm{Br}^{-}$ & $\mathrm{SO}_{4}^{2-}$ & $\mathrm{HCO}_{3}^{-}$ \\
\hline TDs & 1 & 0.77 & 0.71 & 0.89 & 0.62 & 0.95 & 0.69 & 0.58 & -0.07 \\
\hline $\mathrm{Ca}^{2+}$ & & 1 & 0.49 & 0.45 & 0.27 & 0.85 & 0.82 & 0.21 & -0.44 \\
\hline $\mathrm{Mg}^{2+}$ & & & 1 & 0.5 & 0.56 & 0.69 & 0.38 & 0.47 & -0.05 \\
\hline $\mathrm{Na}^{+}$ & & & & 1 & 0.65 & 0.73 & 0.42 & 0.76 & 0.17 \\
\hline $\mathrm{K}^{+}$ & & & & & 1 & 0.51 & 0.28 & 0.52 & 0.42 \\
\hline $\mathrm{Cl}^{-}$ & & & & & & 1 & 0.8 & 0.32 & -0.23 \\
\hline $\mathrm{Br}^{-}$ & & & & & & & 1 & 0.01 & -0.26 \\
\hline $\mathrm{SO}_{4}^{2-}$ & & & & & & & & 1 & 0.19 \\
\hline $\mathrm{HCO}_{3}^{-}$ & & & & & & & & & 1 \\
\hline
\end{tabular}


$\left(\mathrm{Ca}^{2+}, \mathrm{Mg}^{2+}, \mathrm{Na}^{+}, \mathrm{K}^{+}, \mathrm{Cl}^{-}, \mathrm{SO}_{4}^{2-}, \mathrm{HCO}_{3}^{-}\right.$and TDS and $\left.\mathrm{pH}\right)$ analyzed on all 35 samples collected throughout the study area. Eigen values, percentage of the variance of each principal component (PC) and cumulative percentage of variance of five first PCs are given in Table 5 . The first two eigenvalues are $>1$. The scree plot is shown in Figure 3. This figure indicates, according to the elbow and Kaiser criteria, that the first two PCs should be kept for further consideration. They account for $74.7 \%$ of the total variance and are assumed to provide an adequate representation of the overall variance of the data set. Hence, in the factor matrix only these two factors are considered.

The $1^{\text {st }}$ PC (Principal Component) accounts for $52.0 \%$ of the variance in the data set. PC1 is interpreted as relating mainly to the mineralization of the groundwater as it is associated to $\mathrm{Cl}^{-}, \mathrm{Ca}^{2+}, \mathrm{Mg}^{2+}, \mathrm{Na}^{+}, \mathrm{K}^{+}$and TDS. Loadings for these elements on PC1 are high (Table 6). PC1 therefore opposes highly mineralized samples to weakly mineralized samples. PC2 accounts for $22.7 \%$ of the data variance. It is mainly associated to $\mathrm{HCO}_{3}^{-}$and $\mathrm{pH}$. These elements have the highest loadings on this factor. PC2 is thus related to alkaline waters. The plane associated with PC1 and PC2 accounts for $74.7 \%$ of the total variance and is accordingly quite representative of the initial data variability. Figure 4 and Figure 5 show the plot of the variables and of the samples on this plane. PC1-PC2 plane discriminates several groups of samples. It discriminates less mineralized waters lying inland in granitic, gneissic and schistic aquifers (Hafafit, Wadi-el-Jimal, Amira, ...), highly mineralized waters located close to the sea (Abu Ghuson, ...), alkaline waters marked in bicarbonates (El Barramia, Beizah, Hafafit, ...), and waters with lower $\mathrm{pH}$ marked in calcium and bromide (El Asly, Barika, Ghadir, Abu Ghuson, ...).

The $\mathrm{pH}$ of most natural waters is controlled by reactions involving the carbonate system. The relation on PC2 between $\mathrm{pH}$ and carbonates suggest that the high $\mathrm{pH}$ groundwaters could be the result of calcite dissolution or precipitation. Dissolution of a small amount of calcite from minor cements may overcome the buffering capacity of fresh groundwater allowing its $\mathrm{pH}$ to rise. The dissolution of the calcite mineral can take place as:

$$
\mathrm{CaCO}_{3}+\mathrm{CO}_{2}+\mathrm{H}_{2} \mathrm{O} \rightarrow \mathrm{Ca}^{2+}+2 \mathrm{HCO}_{3}^{-}
$$

\section{Spatial Distribution of TDS and of the Main Elements}

Figure 6 shows the spatial distribution of the main elements in the groundwater. The spatial distribution of concentrations depends on several factors such as lithology, the hydrodynamics of the water, the depth of the water

Table 5. Principal component analysis, eigenvalues and explained variance.

\begin{tabular}{ccccc}
\hline Principal component & Eigen values & \% Total variance & Cumulative eigenvalues \\
\hline 1 & 5.200054 & 52.00 & 5.200054 & 7.470655 \\
2 & 2.270601 & 22.70 & 8.301045 & 74.70 \\
3 & 0.830391 & 8.30 & 8.864447 & 83.01 \\
4 & 0.563402 & 5.63 & 9.528826 \\
\hline
\end{tabular}

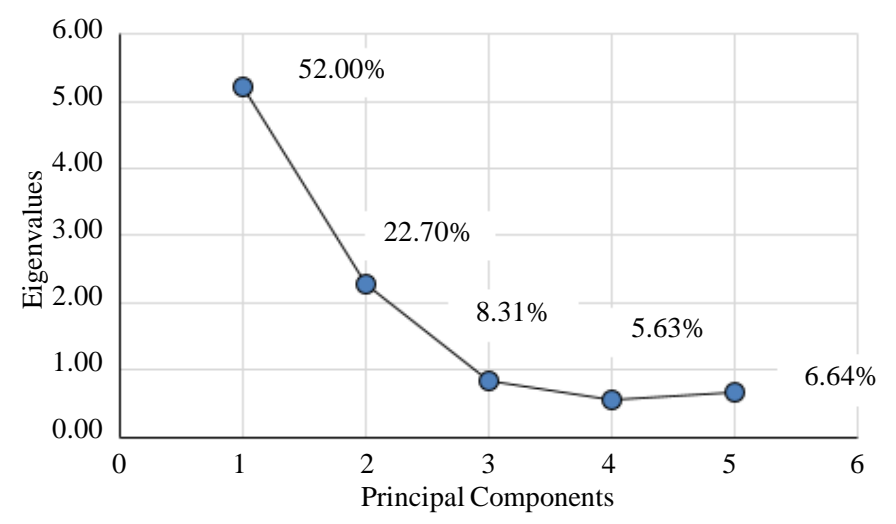

Figure 3. Principal components analysis scree plot. 
Table 6. Chemical variables loadings on principal components 1 and 2.

\begin{tabular}{ccc}
\hline Variables & PC1 & PC2 \\
\hline TDS & $\mathbf{0 . 9 8 9}$ & 0.054 \\
$\mathrm{Ca}^{2+}$ & $\mathbf{0 . 8 1 3}$ & -0.449 \\
$\mathrm{Mg}^{2+}$ & $\mathbf{0 . 7 5 5}$ & 0.105 \\
$\mathrm{Na}^{+}$ & $\mathbf{0 . 8 3 2}$ & 0.376 \\
$\mathrm{~K}^{+}$ & 0.632 & $\mathbf{0 . 6 3 0}$ \\
$\mathrm{HCO}_{3}^{-}$ & -0.109 & $\mathbf{0 . 7 7 4}$ \\
$\mathrm{Cl}^{-}$ & $\mathbf{0 . 9 5 6}$ & -0.184 \\
$\mathrm{SO}_{4}^{2-}$ & 0.561 & 0.553 \\
$\mathrm{Br}^{-}$ & $\mathbf{0 . 7 3 9}$ & -0.428 \\
$\mathrm{pH}$ & -0.338 & $\mathbf{0 . 6 2 8}$ \\
\hline
\end{tabular}

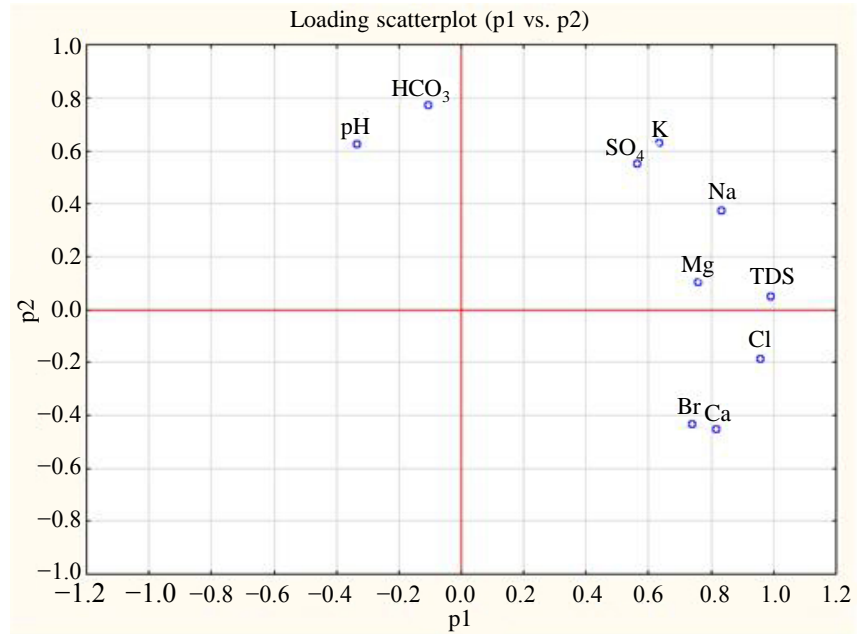

Figure 4. Principal components analysis. Plot of the variables on PC1 vs. PC2.

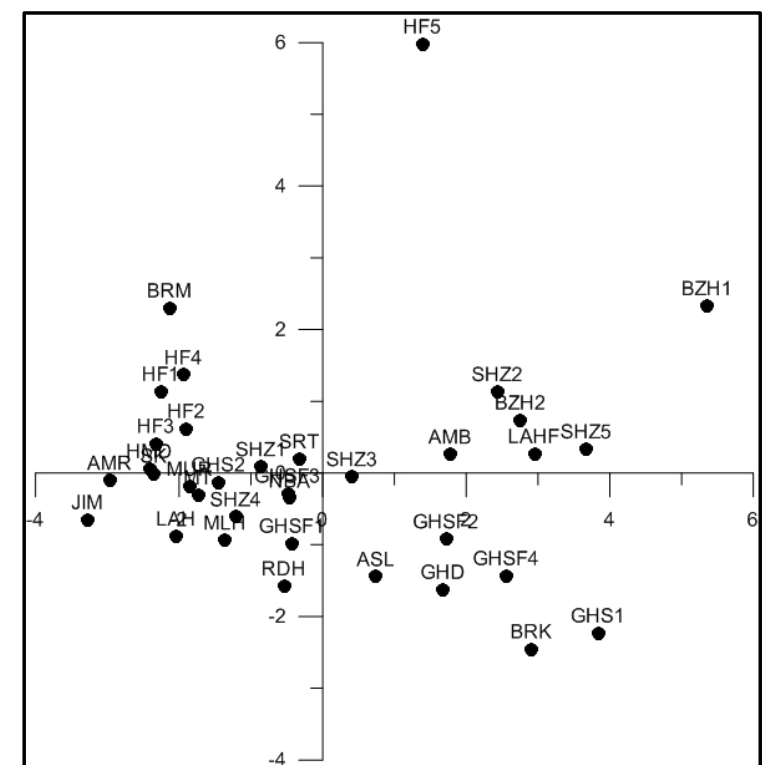

Figure 5. Principal components analysis. Plot of the groundwater samples on PC1 vs. PC2. 

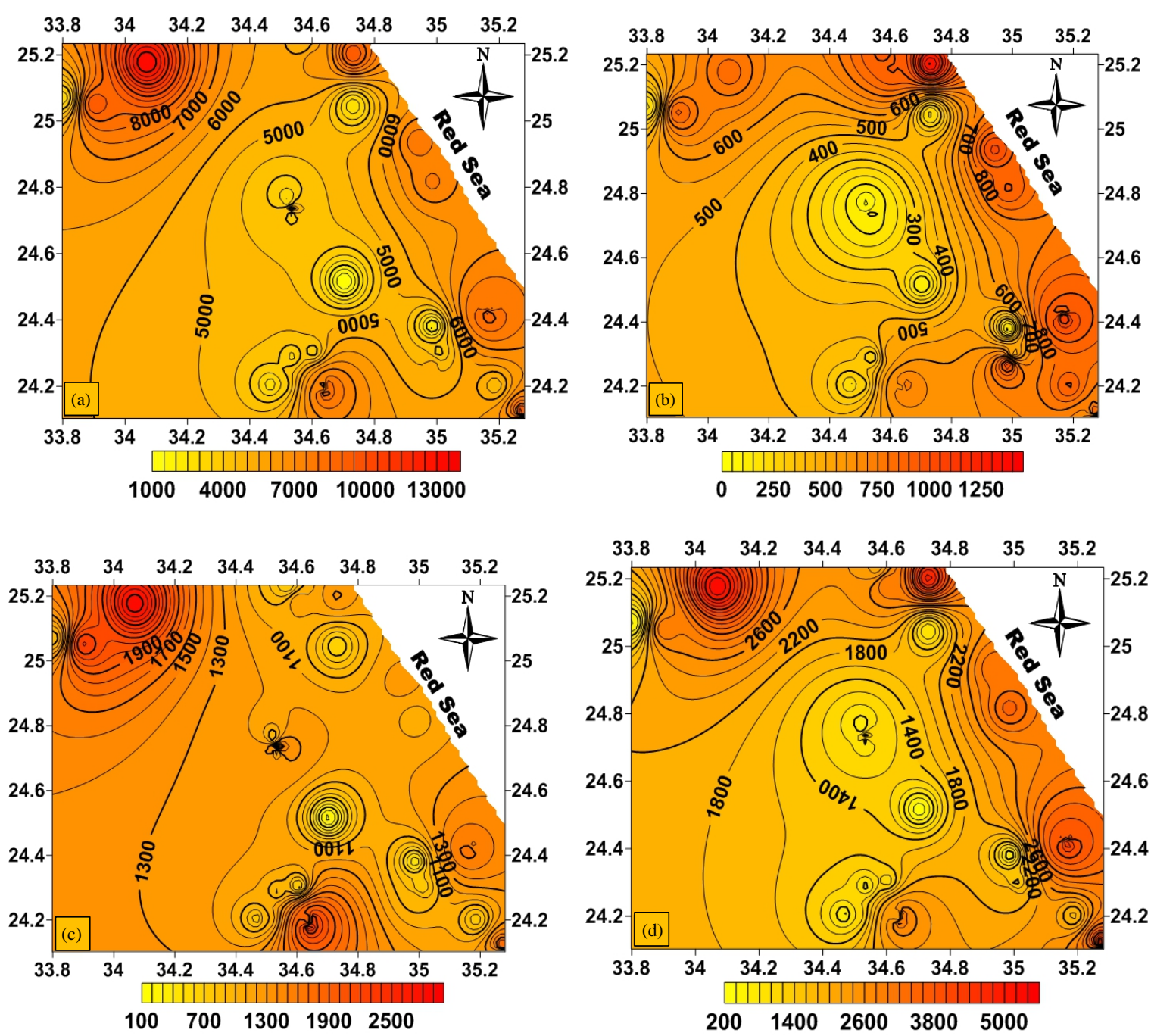

Figure 6. Spatial distribution of TDS and main chemical elements over the study area. (a) TDS; (b) Calcium; (c) Sodium; (d) Chloride.

table, climate conditions and anthropogenic pollution sources. Figure 6 shows that $\mathrm{Cl}^{-}, \mathrm{Ca}^{2+}$ and $\mathrm{Na}^{+}$display relatively equivalent spatial pattern. The highest concentrations of these elements are located along the coastline and on the high peaks of the Red Sea mountains. Low contents are located at the center of the study area, where mainly meta-sediments are found.

The spatial distribution of TDS (Figure 6(a)) is quite similar to that of chloride, calcium and sodium. This corroborates the hypothesis that the main contributors to the groundwater salinity are chloride, calcium and sodium.

\section{Main Hydrochemical Facies}

In order to properly identify the hydrochemical facies and to yield an indication of the qualitative aspects of groundwater, the graphical representation of the results of analysis proves an unavoidable tool. In this study, classification and interpretation of the groundwater hydrochemistry were carried out using the Piper diagram [24]. To achieve this goal, the hydrochemical data were processed with the use of the software Diagrammes [25]. Figure 7 shows the Piper plot of samples. This diagram clearly shows that the groundwater samples have a dominance of chloride and sulfate ions for anions, while sodium is the cation which marks the majority of samples and is followed by the calcium. This reveals the dominance of chloride-sodium facies, and the secondary chloride-calcium and sulfate-sodium facies. 


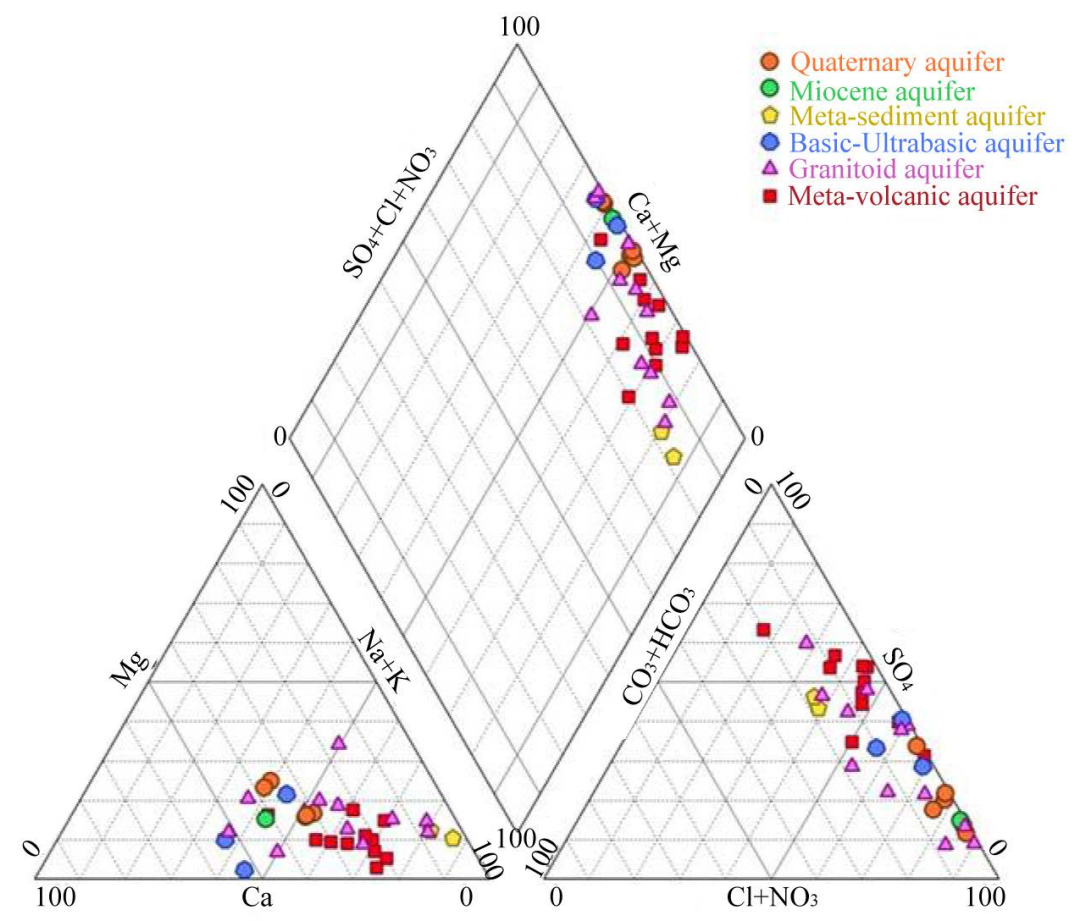

Figure 7. Piper plot of the groundwater samples.

The main hydrochemical facies which characterizes groundwater in each aquifer rock is as following: sulfate-sodium type in meta-volcanic rocks, chloride-sodium and sulfate-sodium types in granitic rocks, chloridecalcium type in basic-ultrabasic rocks. Groundwater in sedimentary rocks displays a chloride-sodium facies (Quaternary rocks) and a chloride-calcium facies (Miocene rocks).

Samples taken in wells close to the Red Sea are of chloride-sodium type, whatever the aquifer, reflecting the effect of marine intrusion.

\section{Binary Diagrams and Mineralization Process}

Dissolved species and their relationship with each other can reveal the origin of solutes and the processes that generated observed composition of the groundwater [26]-[35]. The relationships between concentrations of major dissolved elements are shown in Figure 8. The $\mathrm{Na}^{+}{ }^{-}$s. $\mathrm{Cl}^{-}$relationship has been often used to identify the mechanism for acquiring salinity. The $\mathrm{Na}^{+} \mathrm{vs}$. $\mathrm{Cl}^{-}$plot shows that the samples are not aligned along the 1:1 line, but are quite scattered with a weak correlation $(\mathrm{R}=0.54)$ indicating that $\mathrm{Na}^{+}$and $\mathrm{Cl}^{-}$are not for the most part derived from the same source. Figure 8(a) shows however noticeable enrichments or losses in $\mathrm{Na}^{+}$contents in the groundwater considering $\mathrm{Cl}^{-}$as a conservative element. Molar $\mathrm{Na} / \mathrm{Cl}$ ratios range from as high as 3.91 to 0.41 . High values are found for the meta-volcanic rocks (average $=1.63$ ), the granites (average $=1.14$ ) and the meta-sediments (average $=2.20$ ). The lowest values are found in the sedimentary rocks (average $=0.61$ ). The high $\mathrm{Na} / \mathrm{Cl}$ ratios in crystalline rocks are probably controlled by water-rock interaction, for example, albite (reaction 3) or analcite (reaction 4) weathering according to the following reactions:

$$
\begin{gathered}
2 \mathrm{NaAlSi}_{3} \mathrm{O}_{8}+9 \mathrm{H}_{2} \mathrm{CO}_{3} \rightarrow \mathrm{Al}_{2} \mathrm{Si}_{2} \mathrm{O}_{5}(\mathrm{OH})_{4}+2 \mathrm{Na}^{+}+2 \mathrm{HCO}_{3}^{-}+4 \mathrm{H}_{4} \mathrm{SiO}_{4} \\
\mathrm{NaAlSi}_{2} \mathrm{O}_{6}+3 / 2 \mathrm{H}_{2} \mathrm{O}+\mathrm{CO}_{2} \rightarrow \mathrm{Na}^{+}+\mathrm{HCO}_{3}^{-}+1 / 2 \mathrm{Al}_{2}\left(\mathrm{Si}_{2} \mathrm{O}_{5}\right)(\mathrm{OH})_{4}+\mathrm{H}_{4} \mathrm{SiO}_{4}
\end{gathered}
$$

Samples with low $\mathrm{Na} / \mathrm{Cl}$ ratios are probably the result of $\mathrm{Na}^{+}$loss or exchange with soils and clays. As discussed below, the $\mathrm{Ca}^{2+}$ and $\mathrm{Mg}^{2+}$ data support this idea.

In order to understand the origin of the water salinity due partly to chlorides, the bromide and the chloride ions, which are good conservative tracers in aquifers, are considered. This, because they do not participate in oxydo-reductions reactions and do not form insoluble precipitates [36]. The $\mathrm{Br} / \mathrm{Cl}$ ratio is used in this case to 


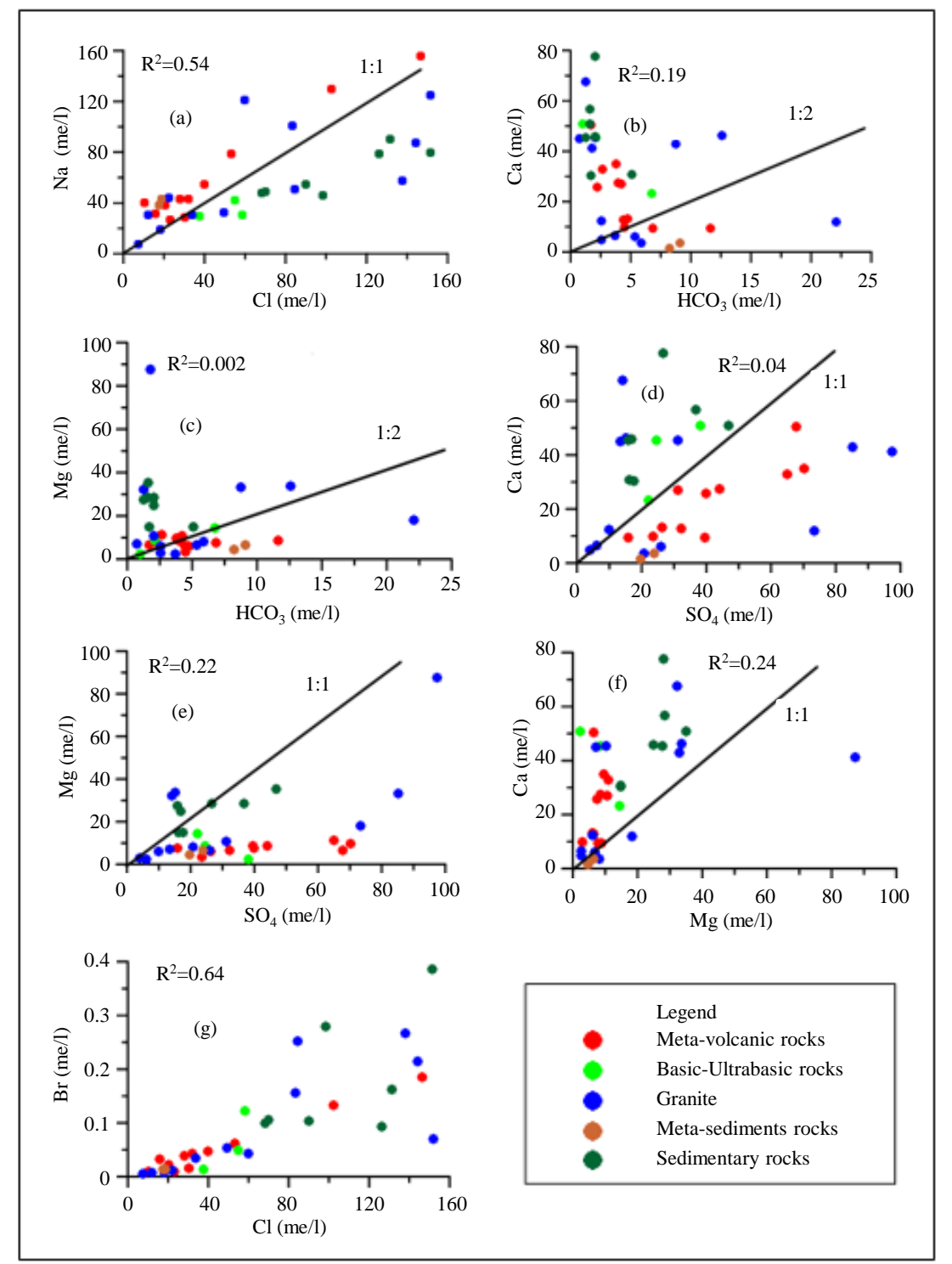

Figure 8. Bi-elements diagrams between the main chemical elements.

determine the origin of salinity. Indeed, it is often the most relevant ratio to explain the salinity of groundwater [37]. The study of the $\mathrm{Br} / \mathrm{Cl}$ ratio allows discriminating the areas under evaporitic influences

Seawater has molar $\mathrm{Cl} / \mathrm{Br}$ ratios of 550 - 700 [38]-[40]. Coastal precipitation has similar $\mathrm{Cl} / \mathrm{Br}$ ratios, however, inland precipitation, especially in arid or semiarid climates, may have lower $\mathrm{Cl} / \mathrm{Br}$ ratios due to the tendency for $\mathrm{Cl}$ to be removed in early rainfall near coastal areas [38] [39] [41]. The average $\mathrm{Cl} / \mathrm{Br}$ are high in the crystalline rocks (Meta-volcanic rocks: $\overline{\mathrm{Cl} / \mathrm{Br}}=1046$; Basic-Ultrabasic rocks: $\overline{\mathrm{Cl} / \mathrm{Br}}=1404$; Granite: $\overline{\mathrm{Cl} / \mathrm{Br}}=1233$; Metasediments: $\overline{\mathrm{Cl} / \mathrm{Br}}=1365$ ). For the sedimentary rocks, the average $\overline{\mathrm{Cl} / \mathrm{Br}}$ is 733 . This value is close to the seawater $\mathrm{Cl} / \mathrm{Br}$ ratio. This shows the effect of seawater intrusion in the sedimentary rocks (Quaternary and Miocene), which are located close to the seaside. In all crystalline and sedimentary rocks within the study area, the $\mathrm{Cl} / \mathrm{Br}$ is much higher compared to the $\mathrm{Cl} / \mathrm{Br}$ ratio of halite, which is about 105 [42]. Thus, halite dissolution must be relatively minor as a cause of increasing salinity in the area.

The excess of $\mathrm{Cl}^{-}$can be explained by the combined effect of another source for this ion than the dissolution of halite, together with the $\mathrm{Na}^{+}$losses due to the phenomenon of base exchanges, as clays in bedrock can release $\mathrm{Ca}^{2+}$ after setting $\mathrm{Na}^{+}$. The excess of $\mathrm{Cl}^{-}$may also have an anthropogenic origin (wastewater, agricultural fertilizers). 
The alkaline earth elements may be derived by dissolution of silicate minerals (e.g., plagioclase feldspar, chlorite, or biotite), carbonates (dolomite or calcite), gypsum, and/or cation exchange of $\mathrm{Na}^{+}$for $\mathrm{Ca}^{2+}$ and $\mathrm{Mg}^{2+}$ on clay minerals. $\mathrm{HCO}^{3-}$ is poorly correlated with $\mathrm{Ca}^{2+}\left(\mathrm{R}^{2}=0.19\right.$; Figure $\left.8(b)\right)$ and $\mathrm{Mg}^{2+}\left(\mathrm{R}^{2}=0.002\right)$. The excess of $\mathrm{Ca}^{2+}$ and $\mathrm{Mg}^{2+}$ indicates that dissolution of carbonate rocks (calcite, dolomite) is not the main source for these elements, which is also backed by the very poor relation of $\mathrm{Ca}^{2+}$ with $\mathrm{Mg}^{2+}\left(\mathrm{R}^{2}=0.24\right)$. Carbonate deposits are absent in the study area, but carbonate cements may be present.

Correlation of $\mathrm{SO}_{4}^{2-}$ with $\mathrm{Ca}^{2+}$ and $\mathrm{Mg}^{2+}$ is also poor (respectively $\mathrm{R}^{2}=0.04$ and $\mathrm{R}^{2}=0.21$; Figure $8(\mathrm{~d})$ and Figure 8(e)) and shows that these elements $\left(\mathrm{Ca}^{2+}, \mathrm{Mg}^{2+}, \mathrm{SO}_{4}^{2-}\right)$ are not derived by the dissolution of gypsum or any Mg-sulfate mineral.

In Figure 8(d) and Figure 8(e), $\mathrm{SO}_{4}^{2-}$ is in excess compared to $\mathrm{Ca}^{2+}$ and $\mathrm{Mg}^{2+}$ in water in metavolcanic rocks. The abundance of sulfates could be attributed to the dissolution of minerals as alunite $\left(\mathrm{KAl}_{3}\left(\mathrm{SO}_{4}\right)_{2}(\mathrm{OH})_{6}\right.$ (reaction 5):

$$
(\mathrm{K}, \mathrm{Na}) \mathrm{Al}_{3}\left(\mathrm{SO}_{4}\right)_{2}(\mathrm{OH})_{6} \rightarrow 3 \mathrm{AlO}(\mathrm{OH})+(\mathrm{K}, \mathrm{Na})^{+}+3 \mathrm{H}^{+}+2 \mathrm{SO}_{4}^{2-}
$$

Excess of $\mathrm{Ca}^{2+}$ compared to $\mathrm{SO}_{4}^{2-}$ in basic-ultrabasic rocks may be caused by means of hydrolysis of plagioclase feldspars, as Anorthite (reaction 6):

$$
\mathrm{CaAl}_{2} \mathrm{Si}_{2} \mathrm{O}_{8}+3 \mathrm{H}_{2} \mathrm{O}+2 \mathrm{CO}_{2} \rightarrow \mathrm{Ca}^{2+}+2 \mathrm{HCO}_{3}^{-}+\mathrm{Al}_{2}\left(\mathrm{Si}_{2} \mathrm{O}_{5}\right)(\mathrm{OH})_{4}
$$

The plot of $\mathrm{Mg}^{2+}$ versus $\mathrm{Ca}^{2+}$ (Figure 8(e)) indicates an excess of $\mathrm{Ca}^{2+}$, which can be explained by the existence of geochemical phenomena such as the $\mathrm{Ca}^{2+} \leftrightarrow \mathrm{Mg}^{2+}$ exchanges during the reactions of precipitation or recrystallization of calcite [43].

Contents of $\mathrm{K}^{+}$in waters are very low compared to the contents of other cations $\left(\mathrm{Na}^{+}, \mathrm{Ca}^{2+}, \mathrm{Mg}^{2+}\right)$. Correlation of $\mathrm{K}^{+}$with $\mathrm{Ca}^{2+}$ and $\mathrm{Mg}^{2+}$ is also rather poor, respectively $\mathrm{R}=0.27$ and $\mathrm{R}=0.56$. The relative amount of $\mathrm{K}^{+}$ contained within the clay minerals with respect to the concentrations in groundwater is probably much larger than $\mathrm{Ca}^{2+}$ or $\mathrm{Mg}^{2+}$. Hence, the reactions amongst the clay minerals are likely to cause larger relative changes in $\mathrm{K}^{+}$than in $\mathrm{Ca}^{2+}$ or $\mathrm{Mg}^{2+}$. This may explain the poorer correlation of $\mathrm{K}^{+}$with $\mathrm{Ca}^{2+}$ and $\mathrm{Mg}^{2+}$, respectively $\mathrm{R}=$ 0.27 and $\mathrm{R}=0.26$.

\section{Ions Exchanges Reactions}

The plots of $\mathrm{Ca}^{2+}$ vs. $\mathrm{HCO}_{3}^{-}$(Figure 8(d)) and $\mathrm{Ca}^{2+}$ vs. $\mathrm{Mg}^{2+}$ (Figure 8(e)) display a substantial excess of $\mathrm{Ca}^{2+}$, showing that the origin of $\mathrm{Ca}^{2+}$ is not the only dissolution of calcite. This is consistent with the hypothesis of a contribution of $\mathrm{Ca}^{2+}$ by ion exchange reaction via a basic reaction such as:

$$
\mathrm{Ca}^{2+}-\text { clay }+2 \mathrm{Na}^{+}(\text {water }) \rightarrow \mathrm{Ca}^{2+}(\text { water }) 2 \mathrm{Na}^{+}-\text {clay }
$$

$\mathrm{Na}^{+}$can exchange $\mathrm{Ca}^{2+}$ and $\mathrm{Mg}^{2+}$ sorbed on the exchangeable sites of the clay minerals, resulting in the increase of $\mathrm{Ca}^{2+}$ and $\mathrm{Mg}^{2+}$ and the decrease of $\mathrm{Na}^{+}$in groundwater. During this process the host rocks are the primary sources of dissolved solids in the water. Groundwater in which the alkaline earths $\left(\mathrm{Ca}^{2+}, \mathrm{Mg}^{2+}\right)$ have been exchanged for the $\mathrm{Na}^{+}$ions is referred to as base-exchange-hardened water [26] (Gupta et al., 2008).

Knowledge of the changes undergone by the chemical composition of the groundwater during its travel in the aquifer is essential. The ion exchange between the groundwater and its host aquifer during travel can be understood analyzing the plot of $\mathrm{Ca}^{2+}+\mathrm{Mg}^{2+}$ versus $\mathrm{SO}_{4}^{2-}+\mathrm{HCO}_{3}^{-}$. In this scatter diagram, the points falling along the equiline $\left(\mathrm{Ca}^{2+}+\mathrm{Mg}^{2+}=\mathrm{SO}_{4}^{2-}+\mathrm{HCO}_{3}^{-}\right)$suggest that these ions have resulted from the dissolutions of calcite, dolomite and gypsum [44]-[47]. If reverse ion exchange is the dominant process, it will shift the points to the left due to a large excess of $\mathrm{Ca}^{2+}+\mathrm{Mg}^{2+}$ over $\mathrm{SO}_{4}^{2-}+\mathrm{HCO}_{3}^{-}$. The analysis of the $\mathrm{Ca}^{2+}+\mathrm{Mg}^{2+}$ versus $\mathrm{SO}_{4}^{2-}+\mathrm{HCO}_{3}^{-}$. Plot (Figure 9) reveals that all the groundwater samples have undergone the process of ion exchanges. Samples taken in the sedimentary, basic-ultra-basic and some samples in granites fall in the $\mathrm{Ca}^{2+}+$ $\mathrm{Mg}^{2+}$ side (Figure 9), suggesting that reverse ion exchange is the major hydrogeochemical process operating in these rocks. All samples taken in the meta-sediments and meta-volcanic rocks and a few samples in granites fall in the $\mathrm{SO}_{4}^{2-}+\mathrm{HCO}_{3}^{-}$side, suggesting exchanges between earth-alkaline in waters and alkaline in clays. Most samples taken in granitic rocks present excess of $\mathrm{Ca}^{2+}$.

Ion exchange process is further discussed using the chloro-alkaline index (CAI) [48], where all values are expressed in meq $\cdot l^{-1}$ : 


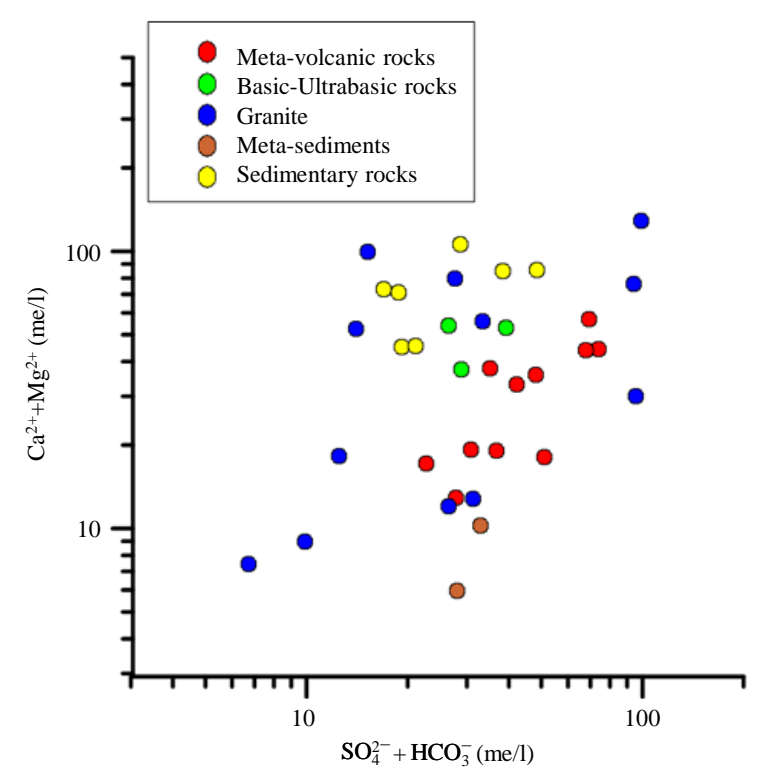

Figure 9. $\mathrm{Ca}^{2+}+\mathrm{Mg}^{2+}$ vs. $\mathrm{SO}_{4}^{2-}+\mathrm{HCO}_{3}^{-}$diagram.

$$
\mathrm{CAI}=\left(\mathrm{Cl}^{-}-\left(\mathrm{Na}^{+}+\mathrm{K}^{+}\right)\right) / \mathrm{Cl}^{-}
$$

This ratio is positive when the sodium and potassium contents are low, i.e. when groundwater has been in contact with minerals able to release the interchangeable alkaline-earth ions easily. These exchanges of ions contained in the matrix with those present in the groundwater are very variable and depend, among other things, on the nature of the substrate. This ratio is negative when the sodium and potassium contents are high, i.e. when groundwater has been strongly in contact with minerals able to release the interchangeable alkaline ions easily. This phenomenon of base exchanges is most generally known with the alumino-silicated clays formed by layers or sheets whose cohesion is ensured by the existence of interlayer ions and water. Indeed, the surface of the layers is negatively charged, thus promoting the possibility of ion exchange with those of the groundwater.

Thus when there is an exchange between adsorbed $\mathrm{Na}^{+}$or $\mathrm{K}^{+}$with $\mathrm{Mg}^{2+}$ or $\mathrm{Ca}^{2+}$ in the groundwater, the CAI will be negative and if there is a reverse ion exchange prevalent (exchange between adsorbed $\mathrm{Mg}^{2+}$ or $\mathrm{Ca}^{2+}$ with $\mathrm{Na}^{+}$or $\mathrm{K}^{+}$in the groundwater) then this index will be positive. The average CAI (Table 7) is positive for the basic-ultrabasic rocks and sedimentary rocks reflecting the substitution of sodium and potassium in groundwater with calcium and magnesium in the underground environment. In meta-volcanic, granites and meta-sediments rocks, this index is in average negative pointing out gain in $\mathrm{Na}^{+}$and $\mathrm{K}^{+}$, and losses in $\mathrm{Ca}^{2+}$ and $\mathrm{Mg}^{2+}$.

The dominance of positive or negative values of the chloro-alkaline index for each type of rocks corroborates well the relationship previously identified between various elements in solution in the groundwater. Despite the specific hydrogeological conditions of the study area, the chloro-alkaline index (CAI), together with the diagram of $\mathrm{Ca}^{2+}+\mathrm{Mg}^{2+}$ versus $\mathrm{SO}_{4}^{2-}+\mathrm{HCO}_{3}^{-}$allowed to understand that the contact of groundwater with the different aquifer rocks supported the spatial variability of ions by the process of base exchanges.

\section{Mineral Saturation Indices}

Saturation indices of minerals are very useful for evaluating the extent to which water chemistry is controlled by equilibrium with solid phases (Appelo and Postma, 1993). The saturation indice (SI) was evaluated using the software PHREEQC V2 [49]. PHREEQC can be used via the freeware DIAGRAMMES [25]. The thermodynamic database used to this purpose is Wateq.dat [50]. The saturation indices of minerals that were suspected to be responsible for the chemical composition of the Eastern desert groundwater were computed. PHREEQC uses the specific ionic concentrations in the water and the mass balance approach to calculate all the stoichiometrically available reactions that are responsible for the observed chemical changes between end member waters [51]. The package calculates the saturation indices, SI, of minerals using the concentrations of the major ions in 
Table 7. Average Choro-Alcaline Index (CAI) and Saturation Indices (SI) of water samples in aquifer rocks types.

\begin{tabular}{ccccccccc}
\hline Rocks types & CAI & SI Dolomite & SI Calcite & SI Aragonite & SI Gypsum & SI Anhydrite & SI Halite \\
\hline Meta-volcanic & -0.64 & 1.55 & 0.92 & 0.78 & -0.28 & -0.50 & -4.57 \\
Basic-ultrabasic & 0.29 & 0.45 & 0.54 & 0.40 & -0.15 & -0.37 & -4.58 \\
Granitoids & -0.16 & 1.66 & 0.85 & 0.71 & -0.57 & -0.78 & -4.50 \\
Meta-sediments & -1.24 & 1.89 & 0.69 & 0.54 & -1.27 & -1.48 & -4.91 \\
Sedimentary & 0.38 & 0.88 & 0.51 & 0.31 & -0.26 & -0.48 & -4.04 \\
\hline
\end{tabular}

the system. The saturation index of a mineral is obtained from Equation (9) [52] [53]:

$$
\mathrm{SI}=\log (\mathrm{IAP} / \mathrm{KT})
$$

where IAP is the ion activity product of the chemical element in solution, KT is the equilibrium constant of the reaction considered at the temperature $\mathrm{T}(\mathrm{K})$. When the $\mathrm{SI}$ is below 0 , the water is undersaturated with respect to the mineral in question. An SI of 0 means water is in equilibrium with the mineral, whereas an SI greater than 0 means a supersaturated solution with respect to the mineral in question.

The saturation indices of the following minerals in all water samples were evauated: calcite, aragonite, dolomite, anhydrite, gypsum and halite. The average values of the SI for each rock type are given in Table 7.

Calculations showed that carbonate minerals have different degrees of saturation. The dolomite SI ranges from -1.18 to +3.90 , that of calcite ranges from 0.02 to +1.79 . Assuming that equilibrium is in the range of -0.5 to +0.5 , the results show that both calcite and dolomite have reached equilibrium in the basic-ultrabasic rocks and are in a state of supersaturation in other rocks.

The evaporitic minerals show degrees of saturation lower than the carbonate minerals. Gypsum SI ranges from -1.49 to 0.13 and anhydrite SI from -1.71 to -0.09 . Water is in equilibrium regarding these minerals in all rocks, except in meta-sediments where it is undersaturated. Halite SI ranges from -5.94 to -3.52 indicating that the groundwater is very undersaturated regarding this mineral. This results also indicates that halite is not the main source for $\mathrm{Na}^{+}$and $\mathrm{Cl}^{-}$.

\section{Role of Evaporation}

The study region experiences dry and semiarid climatic condition, evaporation may also contribute in groundwater chemistry. The sodium versus chloride ratio can be used to identify the evaporation process in groundwater. Evaporation will increase the concentration of total dissolved solids in groundwater and the $\mathrm{Na} / \mathrm{Cl}$ ratio remains the same. It is a rather efficient indicative factor of evaporation. If evaporation is the dominant process, $\mathrm{Na} / \mathrm{Cl}$ ratio should remain constant when TDS increases [54]. Accordingly, the plot of $\mathrm{Na} / \mathrm{Cl}$ versus TDS would give a horizontal line. The TDS versus $\mathrm{Na} / \mathrm{Cl}$ scatter diagram of the groundwater samples (Figure 10) shows that the points fall along a horizontal line which means that the $\left(\mathrm{Na}^{+} / \mathrm{Cl}^{-}\right)$remains almost constant despite the increase in TDS. This indicates that evaporation plays a decisive role in controlling the chemistry of groundwater.

\section{Groundwater Potability Assessment}

The Eastern Desert groundwater potability was assessed according to international standards (WHO 2008) and to the water hardness. The hardness is expressed in French degrees $\left({ }^{\circ} \mathrm{F}\right)$. A French degree $\left({ }^{\circ} \mathrm{F}\right)$ corresponds to the hardness of a solution containing $10 \mathrm{mg} / \mathrm{l}$ of $\mathrm{CaCO}_{3} .1^{\circ} \mathrm{F}$ is equivalent to $4 \mathrm{mg}$ of calcium per liter and $2.4 \mathrm{mg}$ of magnesium per liter. $1 \mathrm{meq}$ of calcium ion is equivalent to $5^{\circ} \mathrm{F}$ [55].

The contents of the main elements of samples were compared with WHO standards [56] and are reported in Table 8. This table shows that no water sample fully meets the WHO criteria for potability. In each rock type, the contents of several elements exceed WHO standards: metavolcanic rocks $\left(\mathrm{Ca}^{2+}, \mathrm{Na}^{+}, \mathrm{Cl}^{-}, \mathrm{SO}_{4}^{2-}\right.$, TDS); basic-ultrasic rocks $\left(\mathrm{Ca}^{2+}, \mathrm{Na}^{+}, \mathrm{K}^{+}, \mathrm{Cl}^{-}, \mathrm{SO}_{4}^{2-}, \mathrm{TDS}\right)$; granites (Na); meta-sediments $\left(\mathrm{Mg}^{2+}, \mathrm{Na}^{+}, \mathrm{K}^{+}, \mathrm{Cl}^{-}, \mathrm{SO}_{4}^{2-}\right.$, $\mathrm{HCO}_{3}^{-}$, TDS), sedimentary rocks $\left(\mathrm{Ca}^{2+}, \mathrm{Mg}^{2+}, \mathrm{Na}^{+}, \mathrm{Cl}^{-}, \mathrm{SO}_{4}^{2-}\right.$, TDS). The TDS limit value is exceeded in all samples except in $8 \%$ of samples in granitic rocks. It appears from this table that only the waters in granitic rocks best meet the WHO criteria for potability. The waters of other rocks are rather far from WHO standards. 


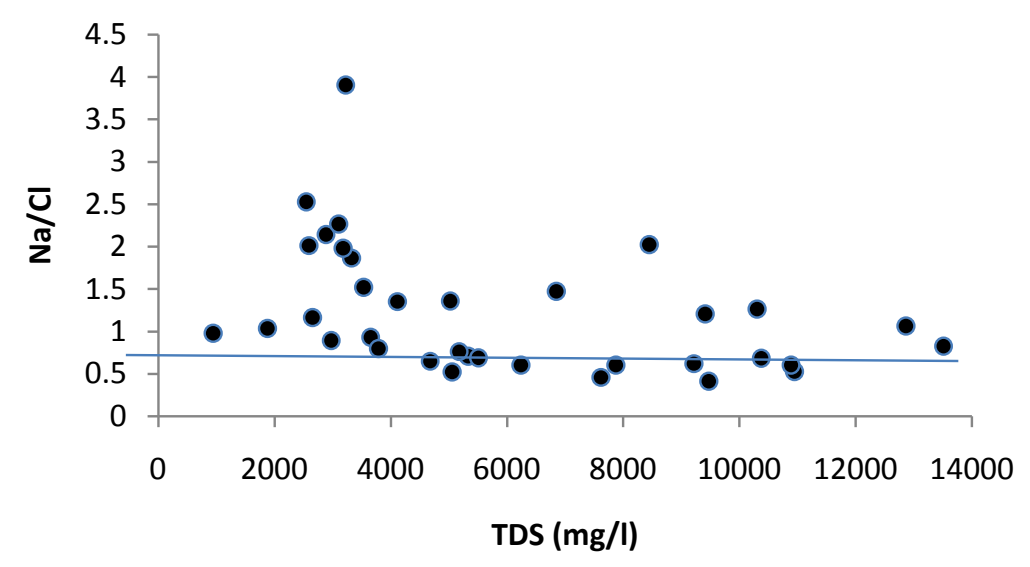

Figure 10. $\mathrm{Na}^{+} / \mathrm{Cl}^{-}$vs. TDS diagram.

Table 8. Percentage of samples having ion concentrations below the WHO standards.

\begin{tabular}{|c|c|c|c|c|c|c|}
\hline Elements & WHO standards & Meta-volcanic (\%) & Basic-ultrabasic (\%) & Granitoids (\%) & Meta-sediment (\%) & Sedimentary (\%) \\
\hline $\mathrm{Ca}^{2+}(\mathrm{mg} / \mathrm{l})$ & 100 & 0 & 0 & 12 & 100 & 0 \\
\hline $\mathrm{Mg}^{2+}(\mathrm{mg} / \mathrm{l})$ & 50 & 9 & 33 & 16 & 0 & 0 \\
\hline $\mathrm{Na}^{+}(\mathrm{mg} / \mathrm{l})$ & 150 & 0 & 0 & 0 & 0 & 0 \\
\hline $\mathrm{K}^{+}(\mathrm{mg} / \mathrm{l})$ & 12 & 63 & 0 & 33 & 0 & 14 \\
\hline $\mathrm{Cl}^{-}(\mathrm{mg} / \mathrm{l})$ & 250 & 0 & 0 & 58 & 0 & 0 \\
\hline $\mathrm{SO}_{4}^{2-} \quad(\mathrm{mg} / \mathrm{l})$ & 250 & 0 & 0 & 16 & 0 & 0 \\
\hline $\mathrm{HCO}_{3}^{-} \quad(\mathrm{mg} / \mathrm{l})$ & 250 & 45 & 66 & 58 & 0 & 85 \\
\hline TDS (mg/l) & 1500 & 0 & 0 & 8 & 0 & 0 \\
\hline $\mathrm{pH}$ & $6.5<\mathrm{pH}<9.5$ & 100 & 100 & 100 & 100 & 100 \\
\hline
\end{tabular}

The hardness ranges from $30^{\circ} \mathrm{F}$ to $643^{\circ} \mathrm{F}$, showing that some samples are soft while other are very hard. The average hardness is as follows for each rock type: Meta-volcanic $=154^{\circ} \mathrm{F}$, Basic-ultrabasic $=241^{\circ} \mathrm{F}$, granites $=$ $242^{\circ} \mathrm{F}$, Meta-sediments $=41^{\circ} \mathrm{F}$, sedimentary rocks $=365^{\circ} \mathrm{F}$. These figures show that hardness is quite high in all rock types, except in the meta-sediments. The contents of magnesium and calcium that exceed the threshold set by WHO, cause such high hardness in these rock aquifers.

These results show that the groundwater in the study area is of poor to bad quality for drinking purpose.

\section{Summary and Conclusions}

Understanding groundwater hydrochemistry and quality is vital to preserve this resource so that it can meet the present and future water needs in many countries. In the Eastern Desert in Egypt, groundwater resources play a vital role in supplying water for drinking, industrial and agricultural purposes. However, there is a lack of knowledge of the groundwater mineralization processes and a lack of rational management. This study adds to our understanding of the chemical properties of groundwater in this area in Egypt.

This study allowed first for a hydrogeological synthesis of the aquifer system in this part of the Eastern Desert. This system is composed of several rock types including Pre-Cambrian crystalline fractured rocks and Tertiary/ Quaternary sedimentary rocks along the Red Sea border. At the scale of the Eastern Desert, all these formations have a hydraulic continuity and form a single aquifer system. The piezometric map displays an N-S divide line. General groundwater flow takes place on either side of this line, to the East toward Red Sea and to the West towards the Nile River.

The hydrogeochemical study of the groundwater was conducted using several methods (Piper diagram, principal components analysis, ions exchanges, saturation indices of various minerals). This study revealed the presence of different hydrochemical facies in each aquifer rock type: chloride-sodium and sulfate-sodium in granitic rocks, chloride-calcium in basic-ultrabasic rocks, chloride-sodium in quaternary rocks and a chloride- 
calcium in Miocene rocks. Close to the Red Sea, groundwater is of chloride-sodium type, reflecting the effect of marine intrusion. The groundwater chemical characteristics are controlled by natural geochemical processes but also by some anthropogenic activities. Evolution of the groundwater chemistry is controlled by multiple processes including natural minerals dissolution as halite or calcite. However silicate weathering and ion exchanges play a prominent role in the ion enrichment of groundwater. Seawater intrusion on the Red Sea coastline and anthropogenic activities affect also the groundwater chemistry. The role of evaporation due to high temperatures in this area was also highlighted.

In the Eastern Desert, the majority of chemical elements analyzed exceed the standards set by WHO. The groundwater is accordingly not perfectly appropriate for human consumption.

The results of this study helped to significantly improve the understanding of the aquifer system of Southern Eastern Desert which is an important resource for the development of this region in Egypt and may contribute as well for a better management of this vital resource.

\section{References}

[1] Andre, L., Franceschi, M., Pouchan, P. and Atteia, O. (2005) Using Geochemical Data and Modelling to Enhance the Understanding of Groundwater Flow in a Regional Deep Aquifer, Aquitaine Basin, South-West of France. Journal of Hydrology, 305, 40-62. http://dx.doi.org/10.1016/j.jhydrol.2004.08.027

[2] Rashed, M., Idris, Y. and Shaban, M. (2006) Integrative Approach of GIS and Remote Sensing to Represent the Hydrogeological and Hydrochemical Conditions of Wadi Qena-Egypt. Proceedings of the 2nd International Conference on Water Resources \& Arid Environment, Saudi Arabia, November 2006, 1-10.

[3] Abd El-Moneim, A.A. (2005) Overview of the Geomorphological and Hydrogeological Characteristics of the Eastern Desert of Egypt. Hydrogeology Journal, 13, 416-425. http://dx.doi.org/10.1007/s10040-004-0364-y

[4] Said, R. (1990) The Geology of Egypt. A.A. Balkema, Rotterdam/Brookfield, 734 p.

[5] El Ramly, I.M. (1972) Final Report on Geomorphology, Hydrology Planning for Groundwater Resources and Reclamation in Lake Nasser Region and Its Environs. Lake Nasser Center and Desert Institute, Cairo, 603 p. (Unpublished Report)

[6] Abdel Kader, A.A. (2001) Application of Some Geophysical and Hydrogeological Techniques for Groundwater Resources Investigation in Selected Areas between Idfu-Marsa Alam, Eastern Desert, Egypt. M.Sc. Thesis, Assiut University, Assiut, 172 p. (Unpublished)

[7] Mohamed, A.A. (2004) Geographic Environment and Development in Marsa Alam Area, Eastern Desert, Egypt. M.Sc. Thesis, Cairo University, Giza. (Unpublished)

[8] Saleh, M.F. (1993) Hydrogeological and Hydrochemical Studies on Some Localities in South Eastern Desert, Egypt. Ph.D. Thesis, Suez Canal University, Ismailia. (Unpublished)

[9] Tahoon, M.A. (2011) Hydrogeochemical and Environmental Study in the Area between Marsa Alam and Baranes, Red Sea Coast, Egypt. Ph.D. Thesis, South Valley University, Qena, 215 p. (Unpublished)

[10] Embaby, A.I., Razack, M. and Porel, G. (2015) Geophysical Investigations to Highlight Hard Rocks Aquifers Structure in the South Eastern Desert, Egypt. 6th International Conference on Water Resources and Sustainable Development, ENSH, Blida, Algeria, 2015, Abstract 4 p.

[11] Domenico, P.A. and Schwartz, F.W. (1990) Physical and Chemical Hydrology. Wiley, New York

[12] Swan, A.R.H. and Sandilands, M. (1995) Introduction to Geological Data Analysis. Blackwell, Oxford.

[13] Gouaidia, L., et al. (2011) Évaluation de la vulnérabilitéd'une nappe en milieu semi-arideetcomparaison des méthodesappliquées: Cas de la nappe de Meskiana (Est Algérien). [Vulnerability Assessment of Groundwater in Semi-Arid and Comparison of Methods: Meskiana Groundwater (Eastern Algeria).] Revue Sécheresse, 22, 35-42. (In French)

[14] Dawdy, D.R. and Feth, J.H. (1967) Application of Factor Analysis in Study of Chemistry of Groundwater Quality, Mojaveriver Valley, California. Water Resources Research, 3, 505-510. http://dx.doi.org/10.1029/WR003i002p00505

[15] Ashley, R.P. and Lloyd, J.W. (1978) An Example of the Use of Factor Analysis and Cluster Analysis in Ground Water Chemistry Interpretation. Journal of Hydrology, 39, 355-364. http://dx.doi.org/10.1016/0022-1694(78)90011-2

[16] Lawrence, F.W. and Upchurch, S.B. (1983) Identification of Recharge Areas Using Factor Analysis. Ground Water, 20, 680-687. http://dx.doi.org/10.1111/j.1745-6584.1982.tb01387.x

[17] Usunoff, E.J. and Guzman, A.G. (1989) Multivariate Analysis in Hydrochemistry. An Example of the Use of Factor and Correspondence Analysis. Ground Water, 17, 27-34. http://dx.doi.org/10.1111/j.1745-6584.1989.tb00004.x

[18] Razack, M. and Dazy, J. (1990) Hydrochemical Characterization of Groundwater Mixing in Sedimentary and Metamorphic Reservoirs with Combined Use of Piper’s Principle and Factor Analysis. Journal of Hydrology, 114, 371-393. 
http://dx.doi.org/10.1016/0022-1694(90)90066-7

[19] Abderamane, H., Razack, M. and Vassolo, S. (2012) Hydrogeochemical and Isotopic Characterization of the Groundwater in the Chari-Baguirmi Depression. Republic of Tchad. Environmental Earth Sciences, 69, 2337-2350. http://dx.doi.org/10.1007/s12665-012-2063-7

[20] Hussein, M.T. (2004) Hydrochemical Evaluation of Groundwater in the Blue Nile Basin, Eastern Sudan, Using Conventional and Multivariate Techniques. Hydrogeology Journal, 12, 144-158. http://dx.doi.org/10.1007/s10040-003-0265-5

[21] Yitbarek, A., Razack, M., Ayenew, T., Zemedagegnehu, E. and Azagegn, T. (2012) Hydrogeological and Hydrochemical Framework of Upper Awash River Basin, Ethiopia: With Special Emphasis on Interbasins Groundwater Transfer between Blue Nile and Awash Rivers. Journal of African Earth Sciences, 65, 46-60. http://dx.doi.org/10.1016/j.jafrearsci.2012.01.002

[22] Taqveem, A.K. (2015) Groundwater Quality Evaluation Using Multivariate Methods, in Parts of Ganga Sot Sub-Basin, Ganga Basin, India. Journal of Water Resource and Protection, 7, 769-780. http://dx.doi.org/10.4236/jwarp.2015.79063

[23] Harman, H.H. (1960) Modern Factor Analysis. University of Chicago Press, Chicago.

[24] Piper, A.M. (1944) A Graphic Procedure in the Geochemical Interpretation of Water Analyses. Transactions-American Geophysical Union, 25, 914-923. http://dx.doi.org/10.1029/TR025i006p00914

[25] Simler, R. (2009) Diagrammes Software. http://www.lha.univ-avignon.fr/LHA-Logiciels.htm

[26] Gupta, S., Mahato, A., Roy, P., Datta, J.K. and Saha, R.N. (2008) Geochemistry of Groundwater, Burdwan District, West Bengal, India. Environmental Geology, 53, 1271-1282. http://dx.doi.org/10.1007/s00254-007-0725-7

[27] Sujatha, D. and Reddy, R.B. (2003) Quality Characterization of Groundwater in the South-Eastern Part of the Ranja Reddy District, Andhra Pradesh, India. Environmental Geology, 44, 579-586. http://dx.doi.org/10.1007/s00254-003-0794-1

[28] Aboubaker, M., Jalludin, M. and Razack, M. (2013) Hydrochemistry Study of a Volcano-Sedimentary Aquifer Using Major Ion and Environmental Isotope Data. Dalha Basalts Aquifer, Southwest of Republic of Djibouti. Environmental Earth Sciences, 70, 3335-3349. http://dx.doi.org/10.1007/s12665-013-2398-8

[29] Moussa, A., Zouari, K. and Oueslati, N. (2008) Geochemical Study of Groundwater Mineralization in the Grombalia Shallow Aquifer, North-Eastern Tunisia: Implication of Irrigation and Industrial Waste Water Accounting. Environmental Geology, 58, 555-566. http://dx.doi.org/10.1007/s00254-008-1530-7

[30] Kuldip, S., Hundal, H. and Dhanwinder, S. (2011) Geochemistry and Assessment of Hydrogeochemical Processes in Groundwater in the Southern Part of Bathinda District of Punjab, Northwest India. Environmental Earth Sciences, 64, 1823-1833. http://dx.doi.org/10.1007/s12665-011-0989-9

[31] Yuce, G. (2007) A Geochemical Study of the Groundwater in the Misli Basin and Environmental Implications. Environmental Geology, 51, 857-868. http://dx.doi.org/10.1007/s00254-006-0460-5

[32] Jalali, M. (2009) Geochemistry Characterization of Groundwater in an Agricultural Area of Razan, Hamadan, Iran. Environmental Geology, 56, 1479-1488. http://dx.doi.org/10.1007/s00254-008-1245-9

[33] Nandimandalam, J.R. (2011) Evaluation of Hydrogeochemical Processes in the Pleistocene Aquifers of Middle Ganga Plain, Uttar Pradesh, India. Environmental Earth Sciences, 65, 1291-1308. http://dx.doi.org/10.1007/s12665-011-1377-1

[34] Diaw, M., Faye, S., Stichler, W. and Maloszewski, P. (2012) Isotopic and Geochemical Characteristics of Groundwater in the Senegal River Delta Aquifer: Implication of Recharge and Flow Regime. Environmental Earth Sciences, 66, 1011-1020. http://dx.doi.org/10.1007/s12665-010-0710-4

[35] Singh, S., Raju, N.J. and Ramakrishna, C. (2015) Evaluation of Groundwater Quality and Its Suitability for Domestic and Irrigation Use in Parts of the Chandauli-Varanasi Region, Uttar Pradesh, India. Journal of Water Resource and Protection, 7, 572-587. http://dx.doi.org/10.4236/jwarp.2015.77046

[36] Fetter, C.W. (1994) Applied Hydrogeology. Prentice Hall Inc., Upper Saddle River, 691.

[37] Usho, R., Kur, H., Jessica, S., Ian, E., Michael, N.F., Stephen, J.S. and Andrea, L.H. (2005) The Use of 36Cl and Chloride/Bromide Ratios in Discerning Salinity Sources and Fluid Mixing Patterns: A Case Study at Saratoga Springs. Chemical Geology, 222, 94-111. http://dx.doi.org/10.1016/j.chemgeo.2005.06.011

[38] Davis, S.N., Whittemore, D.O. and Fabryke-Martin, J. (1998) Uses of Chloride/Bromide Ratios in Studies of Potable Water. Ground Water, 36, 338-351. http://dx.doi.org/10.1111/j.1745-6584.1998.tb01099.x

[39] Davis, S.N., Cecil, L., Zreda, M. and Moysey, S. (2001) Chlorine-36, Bromide, and the Origin of Spring Water. Chemical Geology, 179, 3-16. http://dx.doi.org/10.1016/S0009-2541(01)00312-6

[40] Petrides, B. and Cartwright, I. (2006) The Hydrogeology and Hydrogeochemistry of the Barwon Downs Graben Aqui- 
fer, Southwestern Victoria, Australia. Hydrogeology Journal, 14, 809-826. http://dx.doi.org/10.1007/s10040-005-0018-8

[41] Herczeg, A.L., Torgersen, T., Chivas, A.R. and Habermehl, M.A. (1991) Geochemistry of Ground Waters from the Great Artesian Basin, Australia. Journal of Hydrology, 126, 225-245. http://dx.doi.org/10.1016/0022-1694(91)90158-E

[42] Cartwright, I., Weaver, T.R., Fulton, S., Nichol, C., Reid, M. and Cheng, X. (2003) Hydrogeochemical and Isotopic Constraints on the Origins of Dryland Salinity, Murray Basin, Victoria, Australia. Applied Geochemistry, 19, 12331254. http://dx.doi.org/10.1016/j.apgeochem.2003.12.006

[43] Edmunds, W.M., Kay, R.L.F., Miles, D.L. and Cook, J.M. (1987) The Origin of Saline Groundwaters in the Carnmenellis Granite, Cornwall (UK): Further Evidence from Minor and Trace Elements. In: Fritz, P. and Frape, S.K., Eds., Saline Water and Gases in Crystalline Rocks, Geological Association of Canada Special Paper 33, Geological Association of Canada, St. John's, 127-143.

[44] Datta, P.S. and Tyagi, S.K. (1996) Major Ion Chemistry of Groundwater in Delhi Area: Chemical Weathering Processes and Groundwater Regime. Journal of the Geological Society of India, 47, 179-188.

[45] Rajmohan, N. and Elango, L. (2004) Identification and Evolution of Hydrogeochemical Processes in the Groundwater Environment in an Area of the Palar and Cheyyar River Basins, Southern India. Environmental Geology, 46, 47-61.

[46] Cerling, T.E., Pederson, B.L. and Damm, K.L.V. (1989) Sodium-Calcium Ion Exchange in the Weathering of Shales: Implications for Global Weathering Budgets. Geology, 17, 552-554. http://dx.doi.org/10.1130/0091-7613(1989)017<0552:SCIEIT>2.3.CO;2

[47] Fisher, R.S. and Mulican III, W.F. (1997) Hydrochemical Evolution of Sodium-Sulfate and Sodium-Chloride Groundwater beneath the Northern Chihuahuan Desert, Trans-Pecos, Rexas, USA. Hydrogeology Journal, 10, 455-474.

[48] Schoeller, H. (1977) Geochemistry of Groundwater. In: Brown, R.H., Konoplyantsev, A.A., Ineson, J. and Kovalensky, V.S., Eds., Groundwater Studies-An International Guide for Research and Practice, UNESCO, Paris, 1-18.

[49] Parkhurst, D.L. and Appelo, C.A.J. (1999) User’s Guide to PHREEQC (Version 2)—A Computer Program for Speciation, Batch-Reaction, One-Dimensional Transport, and Inverse Geochemical Calculations. United States Geological Survey, Water Resources Investigations Report 99-4259, Washington DC, 326.

[50] Hounslow, A. (1995) Water Quality Data: Analysis and Interpretation. CRC Press, Boca Raton.

[51] Plummer, L. and Back, W. (1980) The Mass Balance Approach: Application to Interpreting the Chemical Evolution of Hydrologic Systems. American Journal of Science, 280, 130-142. http://dx.doi.org/10.2475/ajs.280.2.130

[52] Appelo, C.A.J. and Postma, D. (1993) Geochemistry, Groundwater and Pollution. Balkema, Rotterdam.

[53] Yidana, S., Ophori, D. and Yakubo, B. (2008) Hydrochemical Evaluation of the Voltaian System. The Afram Plains area, Ghana. Journal of Environmental Management, 88, 697-707. http://dx.doi.org/10.1016/j.jenvman.2007.03.037

[54] Jankowski, J. and Acworth, R.I. (1997) Impact of Debris-Flow Deposits on Hydrogeochemical Process and the Development of Dry Land Salinity in the Yass River Catchment, New South Wales, Australia. Hydrogeology Journal, 5, 71 88. http://dx.doi.org/10.1007/s100400050119

[55] De Fulvio, S. and Olori, L. (1976) Definitions and Classification of Naturally Soft and Naturally Hard Waters. In: Amavis, R., Hunter, W.J. and Smeets, J.G.P.M., Eds., Hardness of Drinking Water and Public Health: Proceedings of the European Scientific Colloquium, Luxembourg 1975, Pergamon Press, New York, 95.

[56] World Health Organization (2008) Guidelines for Drinking-Water Quality. 2nd Edition, WHO, Geneva. http://www.who.int/water_sanitation_health/dwq/2edvol1i.pdf 